\title{
USE OF PLANT GROWTH PROMOTING BACTERIA (PGDB) FOR PROMOTING TOMATO GROWTH AND ITS EVALUATION AS BIOLOGICAL CONTROL AGENT
}

\author{
ELSHAFIE H.S. ${ }^{1}$, CAMELE I. ${ }^{*}$, VENTRELLA E. ${ }^{2}$, SCRANO L. ${ }^{3}$, LOVELLI S. ${ }^{1}$, BUFO S.A. ${ }^{2}$ AND AMATO M. ${ }^{1}$ \\ ${ }^{1}$ School of Agricultural, Forestry, Food and Environmental Sciences, University of Basilicata, Viale dell' Ateneo Lucano, 10, 85100- Potenza, \\ Italy. \\ 2Department of Science, University of Basilicata, Viale dell' Ateneo Lucano, 10, 85100- Potenza, Italy. \\ ${ }^{3}$ Department of European and Mediterranean Cultures, University of Basilicata, Via S. Rocco, 75100- Matera, Italy. \\ *Corresponding Author: Email- ippolito.camele@unibas.it
}

Received: June 20, 2013; Accepted: August 21, 2013

\begin{abstract}
The plant growth promoting effect of some bacteria usable to control plant diseases has a potential for resolving technical problems of plant production. The effects of Burkholderia gladioli pv. agaricicola ICMP11096 on development of tomato seedlings development and control of their infection by Fusarium oxysporum and Sclerotinia sclerotiorum were evaluated in the present study. Bacterized plants showed a higher shoot and root weight and a more extended root system in terms of total length and root density than non-bacterized plants. The bacterizing treatments gave rise to significant reduction of disease symptoms such as leaf wilting induced by $F$. oxysporum infection and/or root necrosis and leaf yellowing by S. sclerotiorum. The potential use of Burkholderia gladioli pv. agaricicola ICMP11096 in biocontrol of fungal pathogens and to enhance seedling growth parameters is underlined as a tool to achieve a high commercial quality of nursery tomato plants.

Keywords- Plant growth promoting bacteria, Burkholderia gladioli pv. agaricicola, Fusarium oxysporum, Sclerotinia sclerotiorum, tomato, biological control
\end{abstract}

Citation: Elshafie H.S., et al. (2013) Use of Plant Growth Promoting Bacteria (PGDB) for Promoting Tomato Growth and Its Evaluation as Biological Control Agent. International Journal of Microbiology Research, ISSN: 0975-5276 \& E-ISSN: 0975-9174, Volume 5, Issue 5, pp.-452-457.

Copyright: Copyright@2013 Elshafie H.S., et al. This is an open-access article distributed under the terms of the Creative Commons Attribution License, which permits unrestricted use, distribution and reproduction in any medium, provided the original author and source are credited.

\section{Introduction}

Recent studies have focused on several beneficial bacterial species, commonly called Plant Growth Promoting Bacteria (PGPB) associated with plant rhizosphere and able to promote a better plant growth. PGPB belongs to genuses of Acinetobacter, Azotobacter, Bacillus, Burkholderia, Erwinia and Rhizobium [1,2].

PGPB action on plant luxuriance can be explained by several mechanisms including production of bioactive metabolites and plant hormones such as auxin [3], cytokinin [4] and gibberellin [5]. The biocontrol effect exhibited by many PGPB can depend on their antagonistic action against phytopathogenic microorganisms by synthesis antibiotics with fungicidal effect, cell-wall degradation enzymes and production of siderophores [6-8]. The colonizing bacteria are able to penetrate into roots either through wounds and cracks of outer protective layers or through root tips or the epidermis middle lamella $[9,10]$.

Most of Burkholderia species can potentially be used as biocontrol agents against phytopathogenic fungi, bacteria, protozoa and nematodes in several different crops such as corn, sweet corn, cotton, grapevine, pea, tomato, pepper and some citrus and apple fruit tree [11-13] due to the production of some antimicrobial substances [14]. Burkholderia sp. strain PsJN is considered an effective PGPB for potatoes, vegetables, and grapevines by reducing the level of the inhibitory hormone ethylene and by secreting a high level of 1aminocyclopropane-1-carboxylic acid deaminase at high level. It has also showed biocontrol effect against some phytopathogenic fungi [15-17].

Burkholderia gladioli has been indicated for in vivo diseases biocontrol because it can completely inhibit conidial germination of Penicillium digitatum and Botrytis cinerea [18]. Metabolites produced by $B$. gladioli also induced a significant inhibition of $P$. expansum growth [19]. Apparently, the mode of action of $B$. gladioli in vivo could be explicated by the synergic combination between its competition for nutrients and/or space and production of antimicrobial metabolites.

Applications of $B$. gladioli showed to increase leaves number and surface as well as number of annual shoots and their diameters in Starking Delicious, Granny Smith, Starkrimson Delicious, Starkspur Golden Delicious and Golden Delicious apple cultivars [20]. However, root length was not significantly different between bacterized and control plants. Root growth is an important parameter in the early stages of plant growth and in response to abiotic stress [21] and it is used as an indicator of nursery plants quality [22]. Therefore, the evaluation of $B$. gladioli as a plant growth promotion agent requires more information on its effect on root growth parameters. 
B. gladioli pv. agaricicola Yabuuchi ( $B g a)$ is a dangerous mushroom pathogen because it causes soft rot of Agaricus bitorquis and $A$. bisporus [23-25]. Bga also showed its potential use as biocontrol agent, since several of its strains inhibit in vitro some pathogenic fungi such as $B$. cinerea, Aspergillus flavus, $A$. niger, $P$. digitatum, $P$. expansum, Sclerotinia sclerotiorum and Phytophthora cactorum [26]. Nevertheless its application for plant growth promotion has not been explored yet.

The aims of this study are:

1. To investigate the plant growth promoting effect of ICMP11096 Bga strain on tomato plants with regard to shoot and root growth parameters;

2. To study its biocontrol effect against Fusarium oxysporum (F.oxy) and S. sclerotiorum (S.scl).

\section{Materials and Methods}

\section{Studied Bacterial and Fungal Strains}

The studied ICMP11096 Bga strain was isolated from A. bitorquis (Quélet) Saccardo and obtained from International Collection of Microorganisms from Plants (ICMP) (Landcare Research, Auckland, New Zealand). Bacterial strains were maintained as lyophilized-dried cultures at $4^{\circ} \mathrm{C}$ and subcultures were grown on the medium King Agar B (KB) for $48 \mathrm{hrs}$. at $25^{\circ} \mathrm{C}$. The studied phytopathogenic fungi were $F$. oxysporum Schlechtend.: Fr. and S. sclerotiorum (Lib.) de Bary, which are important and dangerous pathogens for tomato. These fungi were derived from a pure culture collection maintained at the School of Agricultural, Forestry, Food and Environmental Sciences, Basilicata University, Potenza, Italy and kept on Potato Dextrose Agar (PDA) at $8^{\circ} \mathrm{C}$.

\section{Isolation and Identification of Fungal Pathogens}

F. oxysporum and $S$. sclerotiorum were isolated from symptomatic tomato plants according to Fischer, et al [27]. For their identification, all colonies obtained in vitro were transferred individually, in aseptic conditions, in Petri dishes containing PDA. The colonies developed were used to prepare slides that were subjected to light microscope observation. Molecular analyses based on Polymerase Chain Reaction (PCR) were also used to confirm the identification of fungi isolates. For this purpose, total nucleic acids were extracted with a commercial kit (Dneasy Plant mini kit, Qiagen) according to the manufacturer's instructions. The DNA was amplified using the universal primer pair ITS4/ITS5 [28] whose targets are the Internal Transcribed Spacer regions (ITS) of ribosomal DNA (rDNA). Sterile distilled water was always used as a control. Amplifications were performed with an automated thermal cycler in a $50 \mu$ l reaction volume. Ten microliters of the amplified products, stained with ethidium bromide $\left(0.5 \mathrm{mg} \mathrm{ml}^{-1}\right)$, were visualized using a UV transilluminator after electrophoresis in $1.2 \%$ agarose gel in TAE buffer in presence of a molecular weight marker (1-kb DNA ladder, BRL Life Technologies). After further electrophoresis in $1.5 \%$ agarose gel, the amplicons were sampled, purified with the QIAquick Gel Extraction kit (Qiagen) and directly sequenced. The resulting sequences were compared with those available in GenBank using BLAST software (Basic Local Alignment Search Tool) [29].

\section{Preparation of the ICMP11096 Bga Culture}

A bacterial suspension containing $10^{8}$ Colony Form Unit (CFU) $\mathrm{ml}^{-1}$ of ICMP11096 Bga was prepared from vegetative cells cultured on solid $\mathrm{KB}$ for $24 \mathrm{hrs}$. at $25^{\circ} \mathrm{C}$ and used to obtain the liquid bacterial culture by inoculation of single its $1.5 \mathrm{ml}$ aliquots in $150 \mathrm{ml}$ of liquid
Minimal Mineral (MM). The liquid bacterial culture was then incubated in a shaker at $180 \mathrm{rpm}$ for 7 days at $25^{\circ} \mathrm{C}$ [30] before being used to inoculate tomato plants.

\section{In Vivo Pot Experiment Design}

To study the biological control activity of ICMP11096 Bga strain against phytopathogenic fungi F.oxy and S.scl, a pot experiment was performed in a glass greenhouse at $25^{\circ} \mathrm{C}$ under a $15 \mathrm{hrs}$. photoperiod. Each pot, $20 \mathrm{~cm}$ height and $25 \mathrm{~cm}$ in diameter previously sterilized by immersion in $1.2 \%$ sodium hypochlorite solution for 5 min., was filled with a growing medium mixture (compost: peatmoss, 1:1). Seeds of Solanum lycopersicum L. Cv. cerasiforme were surface sterilized in $70 \%$ ethanol for $1 \mathrm{~min}$. and rinsed 10 times in sterile tap water. Two surface sterilized tomato seeds were sown per each small hole and covered with a $0.5 \mathrm{~cm}$ layer of growing medium. Pots were distributed randomly in a randomized block design in the greenhouse to minimize the experimental errors eventually due to shadow, and were watered once a day. In the experiment, two controls were included: (a) plants treated only with Bga (positive control) and (b) plants not treated either with pathogen or Bga (negative control). Six treatments were done: T1 (F.oxy) + Bga, T2 (S.scl) + Bga, T3 only F.oxy, T4 only S.scl, T5 Plants inoculated with only Bga (positive control) and T6 (negative control; no pathogen and no bacteria). Each treatment was applied to four replicates. The total number of experimental units was 24 and the total number of plants was 288 .

\section{Application of Bacterial Suspension}

The seedling roots were gently washed with sterilized water after appearance of the fourth/fifth true leaf about 10-15 days after sowing (DAS), immerged in the Bga liquid culture for 5 minutes, and repotted. After further 7 days, the liquid Bga culture was uniformly sprayed on the pot surface $(150 \mathrm{ml} / \mathrm{pot})$.

\section{Inoculation of Fungal Pathogens}

Three fungal agar pieces of $0.5 \mathrm{~cm}^{2}$ were cut from a $96 \mathrm{hrs}$. old culture of each tested fungi, inoculated in $300 \mathrm{ml}$ sterilized liquid potato dextrose broth (PDB) and incubated for 10 days at $25^{\circ} \mathrm{C}$ under static condition. Ten days after bacterial inoculation (DAl), $120 \mathrm{ml}$ of the last fungal liquid culture were injected in the soil by using sterile syringes.

\section{Experimental Measurements}

Ecophysiological Parameters. Plant growth was monitored throughout the greenhouse experiment period by recording stem length $(\mathrm{SL})$ and number of leaves (NL) of each tomato plant. Stomatal conductance parameters such as $\mathrm{CO}_{2}$ assimilation rate, transpiration rate and stomata resistance were measured by using an open portable system ADC model LCA-4 infrared gas analyzer (Analytical Development Co., Hoddesdon, UK) in conjunction with a portable temperature and humidity controlled leaf chamber with a $6,25 \mathrm{~cm}^{2}$ surface area.

The final plant growth was assessed at the end of experiment (45 DAS) by measuring the total fresh weights of shoots (TFwS) and leaves (TFwL), total dry weight of leaves (TDwL) and leaf area (LA). The growth of roots was measured using the Image Analysis System (WinRHIZO Arabido, 2009 Software from Regent Instruments Inc., Sainte-Foy, Québec, Canada) by scanning the roots after being gently washing under tap water. The following root parameters were recorded: root depth (RD), total root length (TRL), Root sur- 
face Area (RA), root length per diameter class and total dry weight (TDwR) after oven drying at $70^{\circ} \mathrm{C}$.

\section{Phytopathological Parameters}

The plants were daily observed for monitoring the appearance and development of disease symptoms. Disease severity was assessed using the scale reported in [Table-1].

Table 1- Score chart for comparing disease incidence by F.oxy and S.scl

\begin{tabular}{|llc|}
\hline Scale & Extent of disease development & Symptoms \% \\
\hline 1 & Healthy plant, 0-5 symptomatic leaves / plant & $5 \%$ \\
2 & 6 to 10 symptomatic leaves / plant & $25 \%$ \\
3 & 11 to 25 symptomatic leaves / plant & $50 \%$ \\
4 & 26 to 35 symptomatic leaves / plant & $75 \%$ \\
5 & More than 35 symptomatic leaves / plant & $100 \%$ \\
\hline
\end{tabular}

The symptomatic leaves percentage (IP) was measured by using [eq-1]. The disease index percentage (DI\%) and the control effect percentage $(\mathrm{CE} \%)$ were calculated with [eq-2] and [eq-3], respectively using the formulas described by Lee, et al [2]:

$$
\begin{array}{ll}
\mathbb{P}=(\mathrm{SL} / \mathrm{TL}) \times 100 & {[\mathrm{eq}-1] ;} \\
\mathrm{DI} \%=[\Sigma(\text { Scale } \times \text { No. of SL) } /(\mathrm{HS} \times \mathrm{TL})] \times 100 & {[\mathrm{eq}-2] ;} \\
\mathbf{C E}(\%)=100 \times(\mathrm{DI}-\mathrm{P}-\mathrm{DI}-\mathrm{B}) / \mathrm{DI}-\mathrm{P} & {[\text { eq-3]. }}
\end{array}
$$

Where: SL= Symptomatic Leaves; $\mathrm{TL}=$ Total number of Leaves; $\mathrm{HS}$ = Highest Scale; DI-P = Disease Index of Pathogen treatment; DI-B $=$ Disease Index of Bga treatment

\section{Results and Discussion}

\section{Molecular Identification of Fungal Pathogens}

The resulting sequences showed high similarity with sequences of F. oxysporum (accession number KC311494, KC213775) and S. sclerotiorum (accession number JN232163, GU724513) available in GenBank confirming the identification based on classic methods.

\section{Ecophysiological Parameters \\ Plant Shoot Parameters}

The plants which were only bacterized and those bacterized and inoculated with $S . s c l$ showed significantly higher values $(p<0.05)$ of shoot length and total fresh weight as well as of total leaf dry weight compared to the negative control [Table-2]. The only bacterized plants and bacterized plants inoculated with both pathogens showed significantly higher values of leaf number and total shoot fresh weight [Table-2]. The highest significant values of stem length, total shoot fresh weight and total leaf dry weight $(p<0.05)$ were recorded for the only bacterized plants followed by those bacterized and artificially inoculated with either S.scl or F.oxy.

Table 2- Measurements of plant shoot parameters. Control = negative control, no pathogen and no bacteria

\begin{tabular}{lllllll|} 
Treatments & SL $(\mathbf{c m})$ & NL $(\mathbf{n})$ & TFwS $(\mathbf{g})$ & TFwL $(\mathbf{g})$ & TDwL $(\mathbf{g})$ & LA $\left(\mathrm{cm}^{2}\right)$ \\
Control & $31.38 \pm 4.93 \mathrm{c}$ & $60.06 \pm 7.31 \mathrm{bc}$ & $27.75 \pm 5.07 \mathrm{~b}$ & $9.61 \pm 1.12 \mathrm{c}$ & $1.95 \pm 0.60 \mathrm{c}$ & $4.21 \pm 0.25 \mathrm{~d}$ \\
PIBga & $49.25 \pm 5.29 \mathrm{a}$ & $122.38 \pm 15.68 \mathrm{a}$ & $56.03 \pm 6.39 \mathrm{a}$ & $26.32 \pm 2.92 \mathrm{a}$ & $4.77 \pm 0.92 \mathrm{a}$ & $7.50 \pm 0.49 \mathrm{a}$ \\
PIBga+F.oxy & $43.25 \pm 5.36 \mathrm{~b}$ & $109.25 \pm 11.23 \mathrm{a}$ & $57.35 \pm 7.55 \mathrm{a}$ & $21.94 \pm 1.81 \mathrm{~b}$ & $3.61 \pm 0.70 \mathrm{~b}$ & $5.63 \pm 0.33 \mathrm{~b}$ \\
PIF.oxy & $27.69 \pm 4.02 \mathrm{~cd}$ & $50.06 \pm 9.38 \mathrm{c}$ & $22.48 \pm 6.49 \mathrm{bc}$ & $9.88 \pm 0.95 \mathrm{c}$ & $2.00 \pm 0.63 \mathrm{c}$ & $2.83 \pm 0.18 \mathrm{f}$ \\
PIBga+S.scl & $53.56 \pm 7.16 \mathrm{a}$ & $114.81 \pm 10.64 \mathrm{a}$ & $61.9 \pm 7.24 \mathrm{a}$ & $25.12 \pm 2.68 \mathrm{a}$ & $5.32 \pm 0.90 \mathrm{a}$ & $4.96 \pm 0.33 \mathrm{c}$ \\
PIS.scl & $24.25 \pm 5.88 \mathrm{~d}$ & $67.88 \pm 8.19 \mathrm{~b}$ & $14.45 \pm 4.59 \mathrm{c}$ & $6.61 \pm 1.24 \mathrm{~d}$ & $1.05 \pm 0.29 \mathrm{c}$ & $3.36 \pm 0.29 \mathrm{e}$ \\
\hline
\end{tabular}

PIBga = Plants Inoculated with B. gladioli pv. agaricicola; PIBga+F.oxy = Plants Inoculated with B. gladioli pv. agaricicola and challenged by F . oxysporum; PIF.oxy = Plants challenged by F. oxysporum; PIBga+S.scl = Plants Inoculated with B. gladioli pv. agaricicola and challenged by S. sclerotiorum; PIS.scl = Plants challenged by S. sclerotiorum. Values followed by the same letter in each vertical column are not significantly different according to Tukey test at $p<0.05$. Data are expressed as means of 3 replicates $\pm S D$ s.

\section{Plant Root Parameters}

The bacterized plants and bacterized plants inoculated with pathogens showed the highest significant values $(p<0.05)$ of root length [Table-3], [Fig-1]. Moreover, the bacterized plants showed high dense and well distributed roots in contrast with plants inoculated only with pathogens. The plants treated only with Bga showed the highest significant root depth $(p<0.05)$ followed by bacterized plants and inoculated with either S.scl or F.oxy [Table-3]. The bacterized plants inoculated with $\mathrm{S}$.scl showed the highest significant $(p<0.05)$ of total root dry weight followed by the plants treated only with Bga, then by bacterized plants inoculated with F.oxy [Table-3].

Table 3- Measurements of plant root parameters. Values followed by the same letter in each vertical column are not significantly different according to Tukey test at $p<0.05$. Data are expressed as means of 3 replicates $\pm S D$ s.

\begin{tabular}{|lcccc|} 
Treatments & RD $(\mathbf{c m})$ & TRL $(\mathbf{m})$ & TDwR $(\mathbf{g})$ & RA $\left(\mathbf{c m}^{2}\right)$ \\
\hline Control & $25.06 \pm 2.60 \mathrm{~d}$ & $22.65 \pm 3.12 \mathrm{~b}$ & $0.35 \pm 0.08 \mathrm{~cd}$ & $154.21 \pm 22.28 \mathrm{c}$ \\
IBga & $52.95 \pm 3.59 \mathrm{a}$ & $48.02 \pm 7.32 \mathrm{a}$ & $1.04 \pm 0.15 \mathrm{ab}$ & $489.89 \pm 95.13 \mathrm{a}$ \\
PIBga+F.oxy & $33.53 \pm 2.59 \mathrm{c}$ & $42.87 \pm 1.52 \mathrm{a}$ & $0.68 \pm 0.09 \mathrm{bc}$ & $409.46 \pm 74.77 \mathrm{~b}$ \\
PIF.oxy & $17.36 \pm 1.03 \mathrm{e}$ & $11.89 \pm 2.24 \mathrm{c}$ & $0.23 \pm 0.03 \mathrm{~d}$ & $133.29 \pm 13.55 \mathrm{c}$ \\
PIBga+S.scl & $45.62 \pm 5.57 \mathrm{~b}$ & $48.08 \pm 5.56 \mathrm{a}$ & $1.14 \pm 0.14 \mathrm{a}$ & $490.90 \pm 54.13 \mathrm{a}$ \\
PIS.scl & $18.93 \pm 3.65 \mathrm{e}$ & $11.53 \pm 1.26 \mathrm{c}$ & $0.18 \pm 0.05 \mathrm{~d}$ & $156.88 \pm 26.83 \mathrm{c}$ \\
\hline
\end{tabular}

The highest values of root depth and length, total dry root weight and root surface area were recorded for the bacterized plants and bacterized plants inoculated with S.scl and F.oxy.
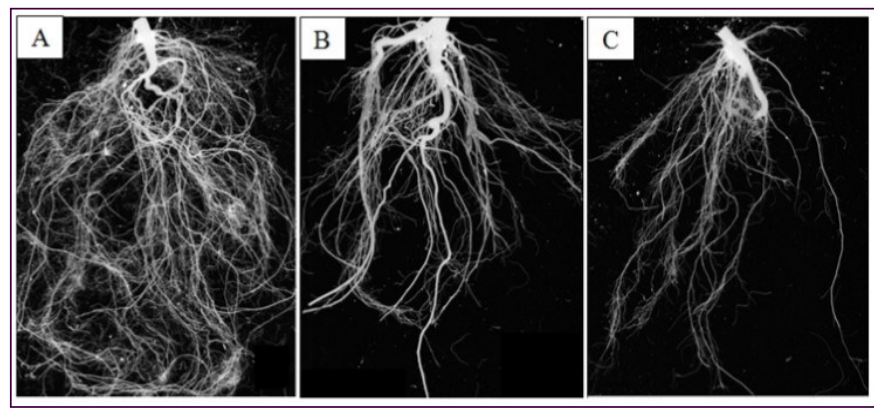

Fig. 1- Tomato plant roots; 1(A): Plant treated with Bga; 1(B): plant only inoculated with F.oxy and 1(C): plant only inoculated with S.scl.

\section{Root Length by Diameter Class}

The inoculation of tomato plants with ICMP11096 Bga strain showed positive effect on formation and distribution of fine roots $(0<\varnothing<0.5 \mathrm{~mm}$ diameter) in the soil compared to treated plants with F.oxy and S.scl, respectively. Moreover, the diameter classes 
$0.5<\varnothing<1.0$ and $1.0<\varnothing<2.0 \mathrm{~mm}$ ascertained in the case of bacterized treatments were also significantly increased $(p<0.05) \mathrm{com}$ pared to non-bacterized and control plants. However, the diameter class $\varnothing>2.0 \mathrm{~mm}$ did not show any significant differences among all treatments [Fig-2]. Bacterized treatments generally showed significantly higher fine root percentages than corresponding nonbacterized plants $(p<0.05)$ except for plants contemporarily treated with Bga and S.scl [Fig-3].

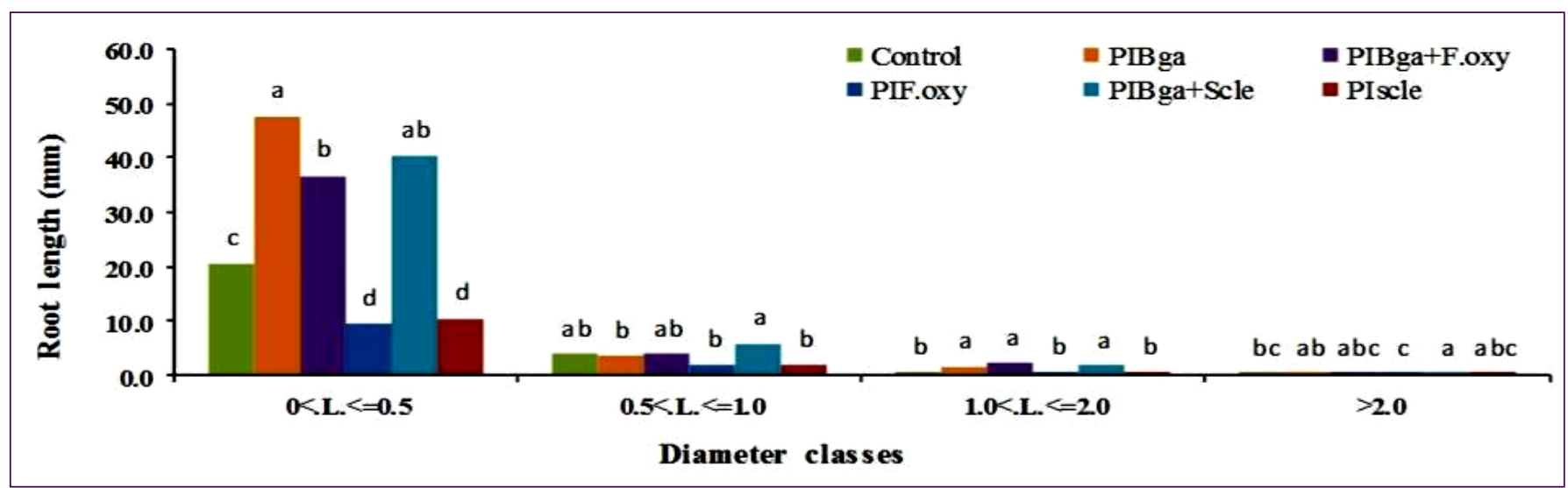

Fig. 2- Root length by diameter class. Bars in each diameter class with different letters indicate mean values significantly different at $p<0.05$ according to Tukey test, Data are expressed as means of 3 replicates \pm SD

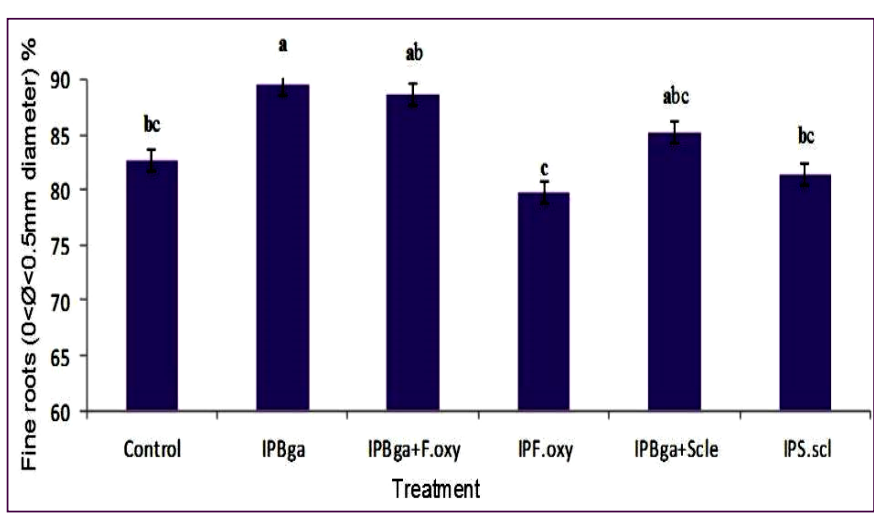

Fig. 3- Percentage of fine roots $(0<\varnothing<0.5 \mathrm{~mm})$. Bars with different letters indicate values significantly different at $p<0.05$ according to Tukey test, data are expressed as mean of 3 replicates \pm SDs.

The application of ICMP11096 Bga strain on tomato increased all plant growth parameters of shoot and root. In fact, the fresh weight values of aerial parts and dry weight of leaves were significantly higher in comparison to non-bacterized plants. Moreover, the relative lengths of aerial parts, number of leaves and leaves area were significantly increased in bacterized plants then control.

The seedling size is commonly related to its successful establishment in open field (e.g. their ability to compete with weeds for light); therefore nursery plants need to reach a minimum size to be marketable. The increase in plant size ascertained with the application of $B g a$ is certainly useful for obtaining a larger tomato seedling size in a shorter nursery cycle and has important economic consequences.

In addition, root depth, total root length and dry weight of roots resulted also significantly increased in comparison with nonbacterized and control plants. An analogous significant increase was noticed for percentage of fine roots $(\leq 0.5 \mathrm{~mm})$.

The rate of advancement of the rooting front in a plant is an important indicator of its ability to use vital resources such as water and minerals [21] and the length of roots and percentage of fine roots are related to water and nutrients uptake and to plant anchorage in soils. Therefore, good root apparatus characteristics contrib- ute to high plant performances and are used for seedling quality evaluation [22]. All beneficial root effects recorded in our experiment therefore suggest a possible application of ICMP11096 Bga strain as a tool for plant management.

Both beneficial effects registered on tomato shoot and root growth could be explained by plant $\mathrm{N}_{2}$-fixing and indol-3- acetic acid producing capacity as described by Barka, et al. [15]. Similar growth promoting effects were also observed by Karakurt and Aslantas [20] who studied B. gladioli and Pseudomonas putida. Their positive results on plant development were attributed to the increase of cell growth through significant enhancement of the cytokinin synthesis. Other results, reported by Jeon, et al. [31], Egamberdiyeva [3], García de Salamone, et al. [4], showed that the application of PGPR strains increased the production of plant growth hormones auxin and cytokinin. On the other hand, Gutiérrez-Mañero, et al. [5] reported that using PGPB of rhizobacteria strains increased the production of plant growth hormone gibberellin. Other similar results concerning the growth promoting effect of Pseudomonas and Bacillus strains on tomato sweet cherry and barley growth, have been attributed to the ability of these bacteria to synthesize auxin and cytokinin hormones, to enhance $\mathrm{N}_{2}$-fixation, to induce phosphate solubilization and to produce antimicrobial substances [32,33].

\section{Stomatal Conductance Parameters}

The rate of stomatal conductance, or its inverse, stomatal resistance, is directly related to the boundary layer resistance of the leaf and to the absolute concentration gradient of water vapor from the leaf to the atmosphere. It is under direct biological control of the leaf through the use of guard cells, which surround the stomatal pore [34].

Results exposed in Table [4] show that there are not significant differences in assimilation rate of carbon dioxide confirming the normal behavior of all bacterized plants compared to control and stressed ones under the same environmental conditions. On the other hand, F.oxy inoculated plants showed a significant reduction of transpiration rate and a marked increase of stomatal resistance [Table-4] which were a clear expression of the negative effect of pathogenicity and virulence of the micromycete. 
Table 4- Stomatal parameters, data are expressed as mean of 3 replicates $\pm S D s$

\begin{tabular}{lccc|} 
Treatments & $\begin{array}{c}\mathbf{C O}_{2} \text { assimilation rate } \\
\left(\boldsymbol{\mu} \mathbf{m o l C O}_{2} \mathbf{m}^{-2} \mathbf{s}^{-1}\right)\end{array}$ & $\begin{array}{c}\text { Transpiration rate } \\
\left(\mathbf{m m o l}_{2} \mathbf{O m}^{-2} \mathbf{s}^{-1}\right)\end{array}$ & $\begin{array}{c}\text { Stomatal } \\
\text { resistance }\left(\mathbf{s ~ c m}^{-1}\right)\end{array}$ \\
\hline Control & $23.65 \pm 3.74 \mathrm{a}$ & $6.79 \pm 0.97 \mathrm{a}$ & $2.88 \pm 1.11 \mathrm{~b}$ \\
IBga & $19.75 \pm 3.52 \mathrm{a}$ & $6.76 \pm 1.21 \mathrm{a}$ & $3.04 \pm 0.59 \mathrm{~b}$ \\
PIBga+F.oxy & $22.58 \pm 7.67 \mathrm{a}$ & $6.71 \pm 2.11 \mathrm{a}$ & $3.25 \pm 1.76 \mathrm{~b}$ \\
PIF.oxy & $19.54 \pm 7.97 \mathrm{a}$ & $4.05 \pm 1.45 \mathrm{~b}$ & $6.39 \pm 2.71 \mathrm{a}$ \\
PIBga+S.scl & $21.02 \pm 3.25 \mathrm{a}$ & $6.25 \pm 1.09 \mathrm{a}$ & $3.47 \pm 0.86 \mathrm{~b}$ \\
PIS.scl & $23.05 \pm 10.78 \mathrm{a}$ & $6.54 \pm 3.04 \mathrm{a}$ & $3.50 \pm 1.95 \mathrm{~b}$ \\
\hline
\end{tabular}

\section{Reduction of Disease Symptoms Effect}

The inoculation with F.oxy led to the development of leaf yellowing symptoms within 10-15 DAl. Moreover, a complete wilting was developed and clearly observed after $30 \mathrm{DAl}$. The inoculation of S.scl gave rise to the formation of leaf chlorosis 15-20 DAl. In addition, the necrosis of roots and stems were observed within 30-45 DAl. A significantly higher $(p<0.05)$ symptomatic leaves percentage was recognized for F.oxy treated plants followed by S.scl [Fig-4]. Furthermore, the plants inoculated with F.oxy showed the significantly highest disease index (68.88\%) followed by plants inoculated with S.scl (46.55\%) compared to the control plants and to those that underwent only Bga treatment ( $2.46 \%$ and $2.73 \%$, respectively) and the plants bacterized and inoculated with both pathogens showed values of control effects close to those of control plants [Table-5].

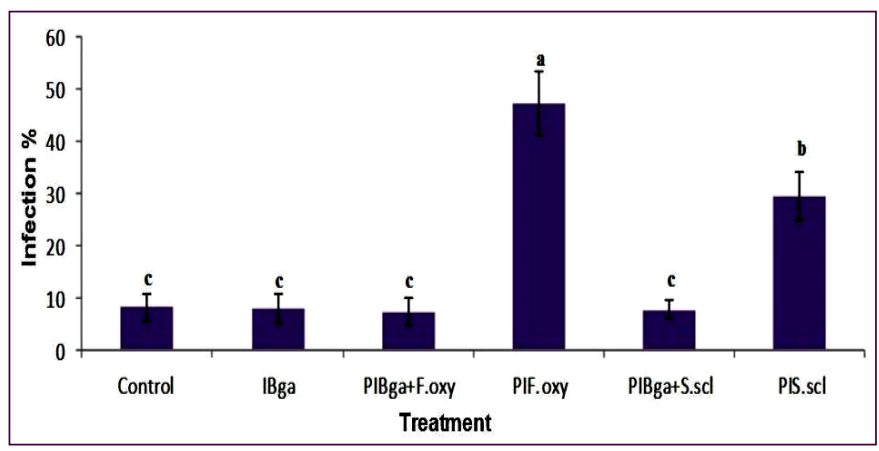

Fig. 4- Symptomatic leaves percentage of tomato. Bars with different letters indicate mean values significantly different at $p<0.05$ according to Tukey test. Data are expressed as mean of 3 replicates \pm SDs. IP $=[($ Symptomatic leaves $/$ Total number of leaves $) x$ 100].

Table 5- Disease index and control effect of plants subjected to different tested treatments

\begin{tabular}{|lcc|}
\hline Treatments & DI\% & CE $\%$ \\
\hline Control & $2.46 \pm 1.83 \mathrm{c}$ & 100 \\
IBga & $2.73 \pm 1.26 \mathrm{c}$ & 100 \\
PIBga+F.oxy & $3.19 \pm 10.09 \mathrm{~b}$ & 94.85 \\
PIF.oxy & $68.88 \pm 1.60 \mathrm{c}$ & 0 \\
PIBga+S.scl & $3.21 \pm 5.44 \mathrm{a}$ & 92.66 \\
PIS.scl & $46.55 \pm 1.12 \mathrm{c}$ & 0 \\
\hline
\end{tabular}

$D I \%$, disease index; CE\%, control effect. Values followed by different letters are significantly different at $p<0.05$ according to Tukey test. Data are expressed as mean of 3 replicates $\pm S D$ s.

The appearance of wilted leaves on the F.oxy treated tomato plants as well as the occurrence of necrosis symptoms on a part of roots and yellowing on some leaves of the S.scl treated plants gave evidence for pathogenic effect of F.oxy and S.scl on epigeous and hypogeous portion of the Solanacea.
The obtained results are promising because the bacterization treatments determined a high reduction of the above symptoms on tomato, demonstrating the control effect exerted by Bga on the two pathogenic fungi studied. The disease index values obtained in the case of F.oxy inoculation were significantly higher than those of all other treatments. Bacterization treatments induced a significant disease protection of tomato plants compared either to nonbacterized plants inoculated with fungal pathogens or to control. The application of bacterial Bga strain could induce a major resistance effect against S.scl than against F.oxy. Similar results have been obtained by Raupach and Kloepper [35] who used mixtures of PGPB strains and induced significant disease protection compared to control against Colletotrichum orbiculare, Pseudomonas syringae pv. lachrymans and Erwinia tracheiphila.

\section{Conclusion}

The applications of ICMP11096 Bga strain suspensions to tomato plants increased both shoot and root growth parameters. These results could be explained hypothesizing that the studied bacterium induced the production of plant growth hormones such as auxin, cytokinin, gibberellin and $\mathrm{N}_{2}$-fixing capacity. The fresh weights of aerial parts and dry weight of leaves of bacterized plants were significantly increased compared to non-bacterized ones. Moreover, the relative lengths of aerial parts, leaf number and leaf area significantly increased after Bga bacterization in competition with nonbacterized control. In addition, the root depth, total root length and dry root weight significantly increased compared to non-bacterized and control plants. The percentage of fine roots were significantly increased in bacterized treatments compared to non bacterized ones and control.

The appearance of wilted leaves on tomato plants only inoculated only with F.oxy and the occurrence of necrosis symptoms on some roots and yellowing of some leaves of plants only inoculated only with S.scl gave evidence for pathogenicity and virulence of both micromycetes on the Solanacea. The obtained results are promising because the bacterizing treatments induced a reduction of the disease severity.

The disease index calculated for tomato plants challenged with F.oxy was significantly higher than those of all other treatments. Tomato plants which were subjected to bacterization with Bga exhibited a significant disease tolerance or resistance compared to non-bacterized ones and control. The application of ICMP11096 $B g a$ strain seemed to trigger an acquired plant systemic resistance (SAR) which appeared more evident against S.scl than against F.oxy. However, further studies are needed to evaluate the possibility of using the studied bacterial strain to protect tomato plant protection in open field.

\section{List of Abbreviations}

Bga: Burkholderia gladioli pv. agaricicola

CFU: Colony Form Unit

ICMP: International Collection of Microorganisms from Plants

PDA: Potato Dextrose Agar

PDB: Potato Dextrose Broth

KB: King $B$

MM: Minimal Mineral

F.oxy: Fusarium oxysporum

S.scl: Sclerotinia sclerotiorum 
PGPB: Plant Growth Promoting Bacteria

DAI: Days after bacterial inoculation

DAS: Days After Sowing

SL: Stem Length

NL: Number of Leaves

TFwS: Total Fresh weights of Shoots

TFwL: Total Fresh weights of Leaves

TDwL: Total Dry weight of Leaves

LA: Leaf Area

RD: Root Depth

TRL: Total Root Length

RA: Root Surface Area

TDwR: Total Dry weight of Root

IP: The symptomatic leaves percentage

DI\%: Disease Index percentage

CE\%: Control Effect percentage

PIBga: Plants Inoculated with B. gladioli pv. agaricicola

PIBga+F.oxy: Plants Inoculated with B. gladioli pv. agaricicola and challenged by $F$. oxysporum

PIF.oxy: Plants challenged by $F$. oxysporum

PIBga+S.scl: Plants Inoculated with B. gladioli pv. agaricicola and challenged by $S$. sclerotiorum

PIS.scl: Plants challenged by S. sclerotiorum

\section{Acknowledgment}

We are grateful to the Italian Ministry of Foreign Affairs for the PhD grant assigned to Hazem Elshafie and to Prof. Gian Luigi Rana for critical revision of the manuscript. Thanks for the technical assistance from C.T. Michele Palumbo and Shimaa Sakr.

Conflict of Interest : The authors declare no conflict of interest

\section{References}

[1] Bashan Y. and de-Bashan L.E. (2005) Encyclopedia of Soils in the Environment, Elsevier, 103-115.

[2] Lee K.J., Kamala-Kannan S., Sub H.S., Seong C.K. and Lee G.W. (2008) World J. Microbiol. Biotecnol., 24, 1139-1145.

[3] Egamberdiyeva D. (2005) J. Plant Nutr. Soil Sci., 168, 94-99.

[4] García de Salamone I.E., Hynes R.K. and Nelson L.M. (2001) Can. J. Microbiol., 47, 404-411.

[5] Gutiérrez-Mañero F.J., Ramos-Solano B., Probanza A., Mehouachi J., Tadeo F.R. and Talon M. (2001) Plant Physiol., 111, 206-211.

[6] Glick B.R. (1995) Can. J. Microbiol., 41, 109-117.

[7] Ciccillo F., Fiore A., Bevivino A., Dalmastri C., Tabacchioni S. and Chiarini L. (2002) Environ. Microbiol., 4, 238-245.

[8] Lucy M., Reed E. and Glick B.R. (2004) Ant. Van Lee., 86, 1-25.

[9] Hurek T., Reinhold-Hurek B., Van Montagu M. and Kellenbberger E. (1994) J. Bacteriol., 176, 1913-1923.

[10]Reinhold-Hurek B. and Hurek T. (1998) Crit. Rev. Plant Sci., 17, 29-54.

[11]Cain C.C., Henry A.T., Waldo R.H., Casida L.J. and Falkinham J.O. (2000) Appl. Environ. Microbiol., 66, 4139-4141.

[12]Perin L., Martinez-aguilar L., Paredes-Valdez G., Baldani J.I., Estrada-de los Santos P., Reis V.M. and Caballero-Mellado J.
(2006) J. Syst. Evol. Micriobiol., 56, 1931-1937.

[13]Scuderi G., Bonaccorsi A., Panebianco S., Vitale A., Polizzi G. and Cirvilleri G. (2009) J. Plant Pathol., 91, 207-213.

[14]El-Banna N. and Winkelmann G. (1998) J. Appl. Microbiol., 85, (1), 69-78.

[15]Barka E., Gognies S., Nowak J., Audran J.C. and Belarbi A. (2002) Biol. Control, 24, 135-142.

[16]Compant S., Reiter B., Sessitsch A., Nowak J., Clement C. and Barka E. (2005) Appl. Environ. Microbiol., 71, 1685-1693.

[17]Compant S., Kaplan H., Sessitsch A., Nowak J., Ait Barka E. and Clement C. (2008) FEMS Microbiol. Ecol., 63, 84-93.

[18]Walker R., Innes C.M.J. and Allan E.J. (2001) Lett. Appl. Microbiol., 32, 346-348.

[19]Altindag M., Sahin M., Esitken A., Ercisli S., Guleryuz M., Donmez M.F. and Sahin F. (2006) Biol. Control, 38, 369-372.

[20]Karakurt H. and Aslantas R. (2010) J. Fruit Ornam. Plant Res., 18(1), 101-110.

[21]Stone L.R., Goodruma D.E., Jaafarb M.N. and Khan A.H. (2000) Agron. J., 93, (5), 1105-1110.

[22]Jacobs D.F., Salifu K.F. and Seifert J.R. (2005) New Forests, 30(2-3), 235-251.

[23]Elshafie H.S., Lamorte D., Lelario F., Bufo S.A. and lacobellis N.S. (2010) Fourth International Conference on Natural Toxins, 99-100.

[24]Lamorte D., Elshafie H., Lelario F., Bufo S.A. and lacobellis N.S. (2010) Proceedings of 6th European Conference Pesticides and Related Organic Micropollutants in the Environment, Bari, Italy, 350-351.

[25]Prashanth S.N., Bianco G., Cataldi T.R. and lacobellis N.S. (2011) J. Agric. Food Chem., 59, 11461-11472.

[26]Elshafie H.S., Camele I., Racioppi R., Scrano L., lacobellis N.S. and Bufo S.A. (2012) Int. J. Mol. Sci., 13, 16291-16302.

[27]Fisher N.L., Burgess L.W., Toussoun T.A. and Nelson P.E. (1982) Phytopathol., 72, 151-153.

[28]White T.J., Bruns T., Lee S. and Taylor J.W. (1990) PCR Protocols: A Guide to Methods and Applications, Academic Press, New York, 315-322.

[29]Altschul S.F., Madden T.L., Schaffer A.A., Zhang J., Zhang Z., Miller W. and Lipman D.J., (1997) Nuc. Acids Res., 25, 33893402.

[30]King E.O., Ward M.K. and Raney D.E. (1954) J. Lab. Clin. Med., 44, 301-307.

[31]Jeon J.S., Lee S.S., Kim H.Y., Ahn T.S. and Song H.G. (2003) J. Microbiol., 41, 271-276.

[32]Aslantas R., Cakmakci R. and Sahin F. (2007) Sci. Hortic., 111, 371-377.

[33]Esitken A., Yildiz H.E., Ercisli S., Donmez M.F., Turan M. and Gunes A. (2010) Sci. Hortic., 124, 62-66.

[34]Zeiger T. (1991) Redwood City, The Benjamin/Cummings Publishing Company, Inc., CA, 92-95.

[35]Raupach G.S. and Kloepper J.W. (1998) Phytopathol., 88, (11), 1158-1164. 